\title{
The USA, Russia and China as a Center of Influence in Global Economy
}

\author{
Irina Minakova ${ }^{1}$, Tatyana Bukreeva ${ }^{2,}$, Olga Solodukhina $^{1}$, and Artyom Golovin ${ }^{1}$ \\ ${ }^{1}$ Southwest State University, Faculty of Public Administration and International Relations, \\ Department of Customs and World Economy, ulitsa Chelyuskintsev 19, 305004 Kursk, Russia \\ ${ }^{2}$ Southwest State University, Faculty of Public Administration and International Relations, \\ Department of International Relations and Public Administration, ulitsa Chelyuskintsev 19, 305004 \\ Kursk, Russia
}

\begin{abstract}
.
Research background. Due to the significant role that the United States, Russia and China play in the world political and economic processes, USRussia-China relations can be recognized as the most important interstate relations in the world, setting the direction for the transformation of the international system. Nowadays, the study of these trilateral relations is a relevant scientific task. The authors, on a systematic basis, have investigated the aspects of interaction between the USA, Russia and China in the modern economy, which opened the way for solving the key issues of international relations. The authors have published several papers on this issue in Russia and abroad, including publications in Scopus and Web of Science indexed journals.

Purpose of the article is to analyse the US-Russia-China relations and to determine the directions of their development in the context of globalization of the world economy.

Methods. To analyse the interests, a systematic method was used that allows considering the interests of the United States, China and Russia as an holistic, complex mechanism with elements constantly interacting with each other.

Findings \& Value added. Despite geographical, linguistic, religious, and other distinctions, the United States, China, and Russia have a lot in common. There were historical periods of active and positive cooperation between these three major superpowers. In our opinion, in spite of the current contradictions between the parties, Russia, China and the United States have a mutual concern in harmonizing trilateral interests. However, the existed contradictions are not insoluble.
\end{abstract}

Keywords: interstate relations; world political and economic processes; the US-Russia-China relations

JEL Classification: $F 01 ; F 02 ; F 51$

\footnotetext{
* Corresponding author: tnbinchina@yandex.ru
} 


\section{Introduction}

At the beginning of the XXI century transformation of the international system is allencompassing and deep in its content. In the international system, the role and place of new centers of influence is increasing, non-traditional security problems are deepening and multiplying, its solution requires the world community's consolidation, which leads to interdependence between states.

After the collapse of the Soviet Union in 1991, a bipolar system of international relations also collapsed. It was replaced by a unipolar world, where the United States as a leader of the coalition of the West actively began to implement the concept of a world order based on American hegemony.

The political role of international organizations (UN, OSCE) coordinated the political positions of different countries has diminished.

The UN's international legal principles were declined. State sovereignty, the most important of them, is a cornerstone of world politics since the middle of the 17th century. The discrepancy between the international legal principles and the existing reality can be illustrated by the following examples:

- the principle of non-use of force and the threat of force: the 2003 invasion of Iraq by the US and the UK, Israeli bombing strikes in Syria; the US and NATO air strikes in Libya in 2011; threats to use force against Iran;

- the principle of non-interference in the internal affairs of states: 'colour revolutions' with the Western support (Yugoslavia, Georgia, Ukraine) or the attempts to implement them (Belarus); illegal supply of weapons during the civil war (Syria). In fact, the West has assumed a role of arbiter in resolving domestic political disputes in other countries all around the world, especially when it comes to countries of great geopolitical importance.

The ideological and theoretical foundations of this approach can be traced in the works of Hedley Bull, who marked out in the international political system the so-called 'international society', a group of states, conscious of certain common interests and common values, form a society in the sense that they conceive themselves to be bound by a common set of rules in their relations with one another, and share in the working of common institutions' [1].

However, nowadays due to economic globalization and appearing of new centers of power and influence, the importance of developing dialogue and expanding interaction in the US-Russia-China trilateral format is increasing.

Purpose of the article is to analyse the US-Russia-China relations and to determine the directions of their development in the context of globalization of the world economy.

The theoretical and methodological basis of the research is formed by an interdisciplinary approach including a systematic methods, identifying the political, economic and military-strategic interests of the US, China and Russia as an integral, complex mechanism, consisting of constantly interacting with each other elements. The study of the interdependence of Russia, China and the US was carried out on the basis of the functional method. The methods of systemic and comparative analysis, statistical methods were used in the study.

The research is based on the works of political scientists, geopoliticians of Russia, the USA, Western Europe, and China. 


\section{Methodology}

To analyse the interests, a systematic method was used that allows considering the interests of the United States, China and Russia as an holistic, complex mechanism with elements constantly interacting with each other.

\section{Research results}

The concepts of globalism and international integration have recently become an integral part of daily life. For all the similarity of centripetal processes that are observed everywhere, there are some areas where a similar movement is either not observed at all, or slowed down to the limit. First of all, these are the spheres of national self-identification, state structure and state independence.

There are at least three huge states in the world presently claiming their own exclusivity, so-called world powers or superpowers. All of them have nuclear weapons, being the centers of power they attract increased attention from the countries unabled to withstand the competition and at the moment forced to be in the orbit of these three states [2 - 4].

First of all, it is the United States of America, a state formed at the end of the 18th century, the first economy in the world, the third state in terms of population, and the fourth in terms of territory. In 2019, with a GDP of USD 21.345 billion, the US retained its leading positions in the world economy and China (China was in second place with a GDP of USD 14217 billion) [5]. These two powers were significantly ahead of Japan ranked third in the world with a GDP of USD 5176 billion.

According to Global Firepower 2020, the United States is currently ranked 1st the most powerful army in the world.

The proliferation of American military installations is one of the indicators of US military power. At the beginning of the 21 st century, the United States had about 400 large bases in different regions of the world. A significant part of the world reads American books, watches American films, listens to American music, this is a phenomenon the American political scientist S. Huntington called 'cocacolonization'. The share of the US dollar in world reserves is about $64 \%[6,7]$.

China, a country with a five-thousand-year history, belongs to the leading countries of the world. It is the second economy in the world, the third country in terms of area and the first in terms of population.

The Center for Economics and Business Research (CEBR) has published a forecast of the economic development of the world's leading countries until 2030 [8]. According to this report, China (with a GDP of USD 33.5 billion) will become the largest economy in the world by 2028 , overtaking the US (with a GDP of USD 32.2 billion).

In the period from 1978 to 2014 , the Chinese economy showed annual growth rate of $9.8 \%$ per year. The country's population has increased from 943.5 million to 1.364 billion. China has become a powerful industrial power: the share of the population employed in industry has increased from $18 \%$ in 1981 to almost 30\% in 2011. Global Firepower ranks China third in army index 2020.

The important starting point for China's integration into world production chains was the country's accession to the WTO in 2001. This event was preceded by more than ten years of hard negotiations.

Since China's accession to the WTO, the United States has opened up its consumer market for China and provided it with export-led growth opportunities, as it was done for 
Japan, Republic of Korea and Taiwan. The growth in trade turned out to be unprecedented: in 2001, the volume of Chinese merchandise imports to the United States amounted to USD 102 billion, and by the end of 2018 it increased to almost USD 540 billion. At the same time, the US deficit in trade with China also increased more than fivefold (from USD 83 billion in 2001 to USD 419 billion in 2018) [9].

Chinese industry currently accounts for over $40 \%$ of the economy. China is the world's main exporter of industrial products. In 2010, every tenth product in the world was made in China.

The share of China in the world production of ships is $45 \%$, mobile phones $-71 \%$, footwear $-63 \%$, computers $-91 \%$, air conditioners $-80 \%$, energy saving lamps $-80 \%$ [10].

The Russian Federation, the successor of the more than a thousand-year Old Russian state, is among the first three world powers. It has the sixth economy in the world, ranking ninth in terms of population and first in the world in terms of area. The territory of Russia is the most important factor potential for Russia to occupy leading positions in the world. Available natural resources can be another criterion for determining the potential of a country. By this criterion, Russia's potential position in the world is even more significant. Most sources indicate that Russia has $22 \%$ of the total natural resources of the world. Russian's share in world reserves of raw materials is estimated by the following indicators: oil $-12 \%$, natural gas $-32 \%$, coal $-11 \%$, potassium salt $-31 \%$, cobalt $-21 \%$, iron $-25 \%$, zinc $-15 \%$, lead $-10 \%$, nickel $-33 \%$, tungsten $-18.2 \%$, tin $-7.6 \%$, platinoids $-10.7 \%$, uranium $-5.3 \%$, antimony $-8.2 \%$ [11]. The well-known American Internet resource 24/7 Wall St. calculated the value of the natural potential of the countries. The calculated resources included oil, natural gas, coal, timber, gold, silver, copper, uranium, iron ore and phosphates. The calculations were based on statistics from the US Geological Survey, the US Energy Information Administration, Bloomberg, and Financial Visualizations. 24/7 Wall St. identified the ten world's most resource-rich countries [12]. The Russian Federation with an indicator of $24.4 \%$ (USD 75.7 trillion) was ranked 1st. This allowed the website to also include Russia among the top five 'luckiest' countries in the world [12]. This list also includes Qatar, Brunei, Norway and the Netherlands, i.e. countries incomparable with Russia in terms of geopolitical power. The USA, ranked second of the world's most resource-rich countries, has an indicator of $14.5 \%$. Thus, Russia beats the US in possible world's resource conflicts. Consequently, to maintain its dominant position, the United States must take steps that undermine Russia's resource potential. It is one of the main reasons to increase external pressure on Russia.

Judging by the resource potential, it is Russia that turns out to be the most secured actor for proposing an independent new world alternative.

Moreover, over the past five years, Russia's GDP has been growing at a rate of about $2 \%$ per year. It is predicted that by 2025 it will take 8th place in the world ranking [13]. Global Firepower 2020 ranked the Russian army as the second most powerful in the world.

Despite geographical, linguistic, religious, and other distinctions, the United States, China, and Russia have a lot in common. For example, they are among the top three arms export leaders, at the same time being permanent members of the UN Security Council along with 'right to veto'; they pursue an exclusively independent policy, different to other states, etc.

Each of these states took its own path to become a leader. The United States, for example, was formed in 1776 on the basis of the colonial system of Great Britain, France, Spain and other countries and further receiving some territories from Mexico and island states such as Puerto Rico. It is a common fact that the United States is a country of former European settlers. There was only one war fought in American territory, and it was civil. 
The People's Republic of China was established in 1949, as the outcome of the civil war, it remains almost completely within its historical borders. During several thousand years of Chinese history, the Chinese have fought many wars, including civil wars and wars against foreign invaders.

According to modern Chinese historians, in the period from 1931 to 1945 , the country lost more than 42 million people fighting against Japanese militarists. The number of deaths puts China in the first place among the countries suffered in the 1930s and 1940s from foreign intervention. The liberation of China's northeastern territories (Manchuria) with the Red Army participation from the Japanese invaders became an important event in modern history of China.

The history of today's Russia starts from 1991, having inherited vast territories from the Soviet Union and the Russian Empire. In 2014, the Republic of Crimea joined Russia. Crimea was a part of the Russian Soviet Federative Socialistic Republic until 1954 when it was transferred to Ukraine at the initiative of N.S. Khrushchev.

From time immemorial, the tribes and ethnic groups settled of the territories of modern Russia fought a lot. These were both internecine wars and conflicts with the closest neighbours, including nomadic tribes, European nations (Germans, French, Poles, Vikings, etc.) and Asian inhabitants (Turks, Persians, Mongols, Tatars, etc.). In the XX century, Russia experienced two world wars and a civil war in its territory; they took away about 33 million people, sowing destruction across the country. No less harm to the state was caused by two changes in social and political formations that took place in 1917 and in 1991.

During the liberal period of the 90s, the loss of human lives in Russia accounted for 30 million; it is the cumulative number of unborn, premature deaths and shortened life expectancy. If the reproduction rate of Soviet Russia in the 80 s had been preserved during these years, then at present the population of Russia would have amounted to 173.5 million people. It would place Russia on the 6th and not on the 9th rank among the countries with the largest human resources in the world.

There were historical periods of active and positive cooperation between these three major superpowers, including cooperation in military sector. It is worth mentioning that in 1863-1864 a squadron of the Russian Imperial Navy was sent to the shores of America to support President Lincoln in the civil war. Another example is the forced offensive of the Soviet troops on the Eastern Front of World War II to prevent defeating of the AngloAmerican troops during the German Ardennes offensive 1944-1945; and the meeting of the Allies at the Elbe in April 1945.

Soviet Russia and Russia almost always had good-neighbourly relations with China, occasionally interrupted by short armed conflicts. Soviet Russia contributed a lot to the development of the People's Republic of China. Modern Russia-China relations can be characterized as friendly and constructive.

Russia in cooperation with China has created such authoritative international organizations as BRICS and SCO; both states have similar approaches to resolving crisis situations in the world, demonstrated in the UN Security Council. Nowadays, two parts are implementing a number of ambitious projects, ranging from the New Silk Road project, continuing with the Power of Siberia gas pipeline and ending with very fruitful cooperation in the field of military weapons. At the end of 2019, trade between the countries exceeded USD 120 billion.

China and the US also actively cooperate in trade. In 2019, the trade turnover between two countries exceeded USD 540 billion. China is one of the main holders of US Treasury bonds (about USD 1.2 trillion).

Since the end of 2017 and the beginning of 2018, the US has been waging a large-scale economic war against China [14 - 19]. 
The purpose of this war is to isolate, weaken, and ideally destroy the high-tech sectors of the Chinese economy. Increased economic pressure on China is associated with a reassessment of its role as a potential economic and technological competitor to the United States [20]. In the early 2010s, China tried to accelerate its technological development and repeat the success of Japan in the 1970s and Republic of Korea in the 1980s and 1990s, becoming a new global centre of high technologies. It made the US to change its attitude towards the technological potential of China. The Chinese approach involves the creation of a significant number of high-tech national flagships with strong competitive advantage over global brands and export products of their own design and manufacture all over the world.

In other words, the existing world famous Chinese companies should be strengthened by new large enterprises, operating in a variety of industries: from information technology to the civil aviation industry.

Currently, China invests tens of billions of dollars in the implementation of projects related to import substitution in the sector of electronic components. The entire process is under the personal supervision of senior party leaders, including the Chinese President Xi Jinping, who visits facilities and meets with senior officials and engineers.

The Internet Plus plan, AI development program, 5G communication technologies program, etc. are the most important technology projects that can lead to significant changes in the global market. China wants to either become a leader or achieve independence in a wide range of sectors: from information and communication technologies to space and aviation industries.

For political control over the gigantic investments in innovative projects, a new administrative body, the Central Commission for Integrated Military and Civilian Development was established in 2017. This body is chaired by Xi Jinping.

The current imbalance in US-China trade has become a convenient topic for the political consolidation of American society around the idea of confrontation with China. By introducing new tariff restrictions for China, Washington is trying to exclude any possibility of a compromise in bilateral relations, ignoring interests of large American companies. In the current situation, it is hard for China to initiate new trade negotiations, as this move will be perceived as a sign of weakness.

Russian-American relations are also developing in a specific way. After the events of December 1991, the Soviet Union ceased to exist, and the West declared its victory in the Cold War, lasted several decades. The massive privatization of state property, organized with the assistance of Western 'consultants', very quickly for negligible money transferred the biggest enterprises specialized on extraction, transportation and processing of hydrocarbons to new owners.

After the 2000 presidential election, the vector of Russia's development was changed, the fight against extremism was put in proper order, the recovery of industrial, agricultural and financial sectors took place. Russia moved from the political principals based on 'recommendations' of Western partners, which caused their dissatisfaction.

The return of the Crimean peninsula to Russia in March 2014 exacerbated relations between Russia and the West. Russia was accused of illegal annexation of Ukrainian territory and imposed sanctions against it by almost all US allies, including the European Union. Over the past 6 years, these sanctions have been steadily expanding, and not only against legal entities, but also individuals.

Due to this, numerous interstate programs were gradually curtailed, and cooperation of interstate commissions was stopped. American businessmen and business establishment from other countries were advised to refrain from doing business both in Russia and with representatives of Russian business circles. In contempt of all international agreements, the property of the Russian Federation has been withdrawn from Russian diplomatic missions 
in the United States, and the number of consulates has been reduced. In addition, a part of the diplomatic corps was expelled from the US.

Nowadays, the sphere of Russia-US relations has narrowed to incredible proportions, which is completely inconsistent with the challenges that the current situation presents to both countries: the spread of terrorism across all continents, health care problems, undermining the foundations of international order, etc.

\section{Discussion and Conclusion}

Thuswise, the USA, China and Russia are the three states currently shaping the global agenda. They are completely different; their distinction from other states brought them to a special place in the international community. Their peaceful existence is not a relic of the past; it is an urgent need for present day. Every state may have economic, financial, and any other interests; but all of them must be within the framework of the rules common to all parts. In this regard, the US, China, and Russia are passengers of one boat, where there is no place for either very selfish requests or outrageous ambitions.

It is necessary to create a harmonious system of consolidated coordination and management of the global process. Particular importance must be focused on the respect for the sovereignty of other countries, regardless of their foreign policy capabilities and the nature of their internal political system; implement uniform standards in evaluation of political processes in the world. i.e. prevention of 'double standards'; respect for the legitimate fundamental interests of other states, readiness for political dialogue without preconditions; acceptance and recognition of world's diversity, including the right of states freely determine their internal political ideology, preserve their national and cultural identity, socio-political and other traditions, civilizational uniqueness; ideals of humanism, social justice, harmonious and peaceful development.

In our opinion, it is necessary to continue the policy of developing dialogue and expanding interaction in the US-Russia-China trilateral format.

Russia needs normal, peaceful and equal relations with China and the United States while maintaining its complete independence.

The research paper is written as part of the state grant for 2020 (№0851-2020-0034).

\section{References}

1. Bull, H. (2002). The Anarchical Society. A Study of Order in World Politics. N.Y.: Columbia University Press.

2. Minakova, I.V., Bukreeva, T.N., Masalov, E.I., Galchenko, S.I., Kharlanova, V.N. (2019). Global management of modern world development: current situation and development prospects. In K. S. Soliman (Eds.), Proceedings of the 33nd IBIMA Conference: Vision 2020: Sustainable Economic Development and Application of Innovation Management (pp. 914-921).Norristown: IBIMA

3. Golovin, A.A., Dobrinova, T.V., Golovin, Al.A, Parkhomchuk, M.A, Vasileva, Z.A. (2019). Study of foreign trade policy of the developed and developing world economies. In K. S. Soliman (Eds.), Proceedings of the 33nd IBIMA Conference: Vision 2020: Sustainable Economic Development and Application of Innovation Management (pp. 1574-1585). Norristown: IBIMA.

4. Minakova, I.V., Bukreeva, T.N., Parkhomchuk, M.A., Golovin, A.A. (2018). Modern Economic Development: Problems and Prospects. In K. S. Soliman (Eds.), 
Proceedings of the 31st IBIMA Conference: Innovation Management and Education Excellence through Vision 2020. (pp. 2975-2981). Norristown: IBIMA.

5. Gay, J. (2020, July 7). Classement PIB: la liste des pays les plus riches du monde en 2020. Journaldunet. https://www.journaldunet.fr/patrimoine/guide-des-financespersonnelles/1209268-classement-pib/.

6. World economy in 2017 and forecast of changes in 2020 and 2030. (2017, February). Golos. https://golos.io/ru--yekonomika/@romapush/mirovaya-ekonomika-v-cifrakh2017-g-i-prognoz-izmenenii-na-2020-i-2030-gg.

7. The dollar will continue to dominate global reserves, UBS said. (2019, November 19). Yandex. https://zen.yandex.ru/media/id/5c34c677cffc6400aaed02c4/dollar-prodoljitdominirovat-v-globalnyh-rezervah-schitaet-ubs5da7644d0ce57b6566438f83?utm_source=serp.

8. Forecast center for economics and business research: economic development of the world's leading countries until 2030. (2013, December 31). Gtmarket. https://gtmarket.ru/news/2013/12/31/6561.

9. Zotin, A. (2019, July 2). USA and China: more than a trade war. Econs. https://econs.online/articles/ekonomika/ssha-i-kitay-bolshe-chem-torgovaya-voyna/.

10. China's trade. (2019, June 17). Visasam.

https: // visasam.ru/emigration/economy/promyshlennost-kitaya.html

11. Minakova, I.V., Bukreeva, T.N., Parkhomchuk, M.A., Golovin, A.A. (2018). Global Natural Resources Management in Modern Conditions. In K. S. Soliman (Eds.) Proceedings of the 31st IBIMA Conference: Innovation Management and Education Excellence through Vision 2020 (pp. 5135-5138). Norristown: IBIMA.

12. Sauter, M.B. (2012, April 18). The World's Most Resource-Rich Countries. 247wallst. http://247wallst.com/special-report/2012/04/18/the-worlds-most-resource-rich-count.

13. Situation et perspectives de l'économie mondiale 2020: Résumé analytique. (2020, January 16). UN official website.

https://www.un.org/development/desa/dpad/publication/situation-et-perspectives-deleconomie-mondiale-2020-resume-analytique/

14. Lebedeva, L.E. (2020). Foreign trade policy under D. Trump: risks and challenges at the state level. Mirovaya ekonomika i mezhdunarodnye otnosheniya, 64(7), 43-48.

15. Li, S.M., Farrell, M. (2020). The emergence of China, Inc.: behind and beyond the trade war. International Journal of Emerging Markets, Early access.

16. Yin, W. (2020). A comparison of the US and EU regulatory responses to China's state capitalism: implication, issue and direction. Asia-Europe Journal, 1-25.

17. Kashin, V.B., Piatachkova, A.S., Krasheninnikova, L.S. (2020). Chinese economic sanctions policy: theory and practice. Comparative Politics Russia, 11(2), 123-138.

18. Kwan, C.H. (2020). The China-US Trade War: Deep-Rooted Causes, Shifting Focus and Uncertain Prospects. Asian Economic Policy Review, 15(1), 55-72.

19. Swenson, D.L., Woo, W.T. (2019). The Politics and Economics of the US-China Trade War. Asian Economic Papers, 18(3), 1-28. DOI: 10.1162/asep_a_00710.

20. Broz, J.L., Zhang, Z.W. Wang, G.Y. (2020). Explaining Foreign Support for China's Global Economic Leadership. International organization, 74(3), 417-452. 